\title{
Ideological Education and Management of Students under the Socialization of Student Apartment
}

\author{
Yong Sheng \\ Student Affairs Office of Chifeng University
}

Keywords: Student apartment management; Ideological and political education; Socialization

\begin{abstract}
In recent years, with the reform of higher education system, logistics services such as school apartment management have gradually shifted towards the direction of socialization. This change puts forward higher level requirements for the management of student apartments and the ideological and political education of college students under the conditions of socialization. This article mainly analyzes the urgency and necessity of ideological and political education in the process of student apartment management and the problem of how to coordinate the relationship between management and education.
\end{abstract}

\section{Introduction}

Nowadays, with the rapid development of social economy and culture, the traditional management mode of student apartments is undergoing unprecedented challenges. The apartment management no longer only provides management work, but also services schools and students, so as to provide convenient and quick service for school, students' study and daily life. However, at the same time, the apartment management still bears the tasks of ideological and political education management for students, and the reality has told us that this task has a long way to go.

\section{Problems of College Students in Apartment Management}

In recent years, due to the explosion of college students in universities and colleges, students have made a great change in the concept of life, the way of consumption and the demand. The large gap between the rich and the poor among the students makes the difficulty of the student apartment management services increase. Some students lack morality, ignore the interests of collectives and others, and take themselves as the center. In the apartment, they indulge in the network, play games, smoke, drink, say vulgar words, abandon their studies, even steal their roommates' belongings, resulting in interpersonal tension in the dormitory. Academic problems, employment problems, poor students problems, ideological problems and psychological problems plague the growth of students. Facing these realistic challenges, the ideological and political education in apartment management is imminent. The times are different, so the specific requirements for the apartment management are also changing. In addition, there are many new problems that should be paid attention to in management services, such as environmental health, financial security, collective mental outlook, code of conduct, etc. In addition to the need for student apartment to strengthen their management services, the above problems highlight the urgency, importance and necessity of carrying out ideological and political education in apartment. Ideological and political education in students' apartments should be a very important part of the new apartment management model. Its success or failure is not only positively related to the success or failure of dormitory management, but also positively related to the healthy or unhealthy growth of students.

\section{Factors Influencing the Development of Ideological and Political Education Work in Students' Apartments}

Therefore, in this new situation, the apartment management should adhere to the people-oriented principle, and further improve the three functions which are education, management and service with the scientific attitude by taking the construction of harmonious campus and harmonious 
apartment as the goal, and this should be taken as the goal of the development of apartment construction. The student apartment, as an indispensable part of the university and a place where educators are highly concentrated, should have certain functions of ideological and political education, no matter what kind of management mode is adopted. However, there are still some factors that affect the development of the ideological and political education work of the students' apartments, which mainly include:

Firstly, after enrollment expansion of universities, the number of student apartment and accommodation are much higher than any previous period. This also makes the intensity of student concentration in apartment reach an unprecedented level. All kinds of thoughts influence each other, so it is urgent to guide them by using unified and correct ideas. Secondly, the implementation of credit system in college teaching reform makes the class concept of students become weak. The learning links of students between college and college increase, the mobility increases, the study time in the apartment increases and the attachment to the apartment increases, so the requirement for the ideological and political education of apartment is put forward subjectively. Moreover, the time online spent by students in the apartment increases, the opportunities that students know and contact society increase and the chances of being affected by bad ideas also increase, therefore, how to prevent students from being eroded by harmful ideas is also a big problem for apartment managers. Thirdly, in the new situation, there are great changes in the group characteristics and individual characteristics of college students. Today, most students are only children. They lack of social knowledge, social ability and self-care ability, so there are many unsatisfactory aspects in the apartment, such as self-discipline, self-management, self-service, communication with others, and harmony with others. These factors not only increase the difficulty of apartment management, but also put forward a test for the development of ideological and political education of apartment and the achievement of the expected goal. These questions require that the student apartment should carry out the educational function of the management of the student apartment from many angles and all directions, including the stimulation, demonstration, guidance, warning, reward and punishment for the aspects of students' study, daily life, behavior norms, psychology and physiology.

\section{Apartment Management Requirements}

In the new situation, colleges and universities must constantly enrich their management thoughts, actively promote the change of management thoughts, and constantly strengthen the consciousness of education and management according to law. At the same time, students are also the real consumers, so the rules and regulations formulated by the apartment should fully consider the basic rights and interests of the students. In management, the education administrators and students should treat each other as equals, and the managers should pay attention to the rationality, humanity and affinity of ideological and political education and increase the art of education and management. The apartment management services of universities are different from other social property services, because it also has the function of education, however, this can not deny the fact that students are consumers. The development of the management and ideological and political education work should be based on students, start from the basic interests of students, improve service attitude and improve service quality, so as to build a good life and learning environment for all teachers and students.

\section{The Development of the Ideological and Political Education Work of Student Apartment}

At present, the way of university students accepting education in university presents diversified development trends. Therefore, the ways and methods of ideological and political education in colleges and universities will also change. Student apartment is an important place for students to study, live, communicate and rest. Most of the students studying in the school spend more than half of their time in the dormitory. Therefore, our apartment managers should strengthen the ideological and political education work of students' apartments, and explore new ways. 
Firstly, Schools Should Actively Develop the Educational Function of Student Apartments. The traditional teaching organization form in colleges and universities is changing day by day and the implementation of credit system makes the class concept of students become weak. The learning links of students between college and college increase, the study and live time of students in the apartment increases and the effect of network culture on students also increases, so the traditional ideological and political education which takes the classes and classrooms as active units can not continue to guarantee good educational goals. The apartment has shown great advantages in ideological and political education, so our apartment managers must balance the traditional working methods and the reality changes, pay attention to the education function of student apartments, give full play to the education function of the apartment management services and do the work of ideological and political education of student apartments well.

Secondly, Schools Should Coordinate Ideological and Political Education. After the reform of university logistics, the original ideological and political education can not be carried out in the original way, and the management mode of college students' apartments shows diversified development trends. Therefore, the work of political and ideological education in university apartments has not been strengthened. The ideological and political education management in university should actively adapt to the new situation, improve the working methods, and set up a special administrative institution for ideological and political education of apartment. It should be also in charge of reaching a consensus with a number of existing departments to jointly integrate educational management resources, set up a strong team and work actively, and do well in ideological and political education in students' apartments by using the advantages of group guidance and professional work.

Finally, Schools Should Change the Mode of Ideological and Political Education. In recent years, the ideology and value orientation of students have shown the characteristics of diversification and complexity. If we want to make the ideological and political education of students receive actual results, the targeted education work should be carried out by using scientific work methods. With the increasing of socialization of university campus, the study and life of students in an open and complicated environment are closely related to society, which will make the space-time view of our ideological and political education change, and expand because of the expansion of the time and space of students' study and life. The increase of the students' time in the apartment will make the focus of ideological and political education gradually incline from the traditional mode of ideological and political education in colleges and departments to the ideological and political education mode which takes apartment as the key point. Starting from the daily school life, many kinds of forms and methods should be used to carry out the all-round ideological and political guidance and education for students.

\section{Conclusion}

The idea of carrying out ideological and political education in students' apartments is not only suitable for the needs of the reform and development of higher education, but also conforms to the management situation of contemporary university education. It is also a good form of optimizing and integrating the educational management resources of higher education. "Entering" is the key to solve the problem of apartment education. "Entering" means progress, but the "non entering" refers to inaction. Therefore, fundamentally speaking, the process of socialization of university apartment management should be the process of college students' ideological and political work entering the apartments. The role of the position function of students' apartments in ideological and political education should be fully exploited, in this way, the management and service for student apartment can be enhanced. The two complement each other and promote each other. 


\section{References}

[1] P.Ding: Reflections on the Practical Significance of Ideological and Political Education in Colleges and Universities under the New Situation[J], Journal of Shandong Youth Administrative Cadres College, 2010(5).(In Chinese)

[2] X.H.Li and J.P.Tang: Analysis of the Relationship between Demand and Effect of Ideological and Political Education in Universities[M], Yunnan University Press, 2009.(In Chinese)

[3] H.Zhang: The Important Position of Students' Ideological and Political Work -University Apartment[J], Journal of Southwest University for Nationalities(Natural Science Edition), 2006(10).(In Chinese)

[4] Y.H.Wang: Discussion on Ideological and Political Education of Students under the New Situation of University Rear Service Socialization[J], Fujian Normal University, 2007.(In Chinese) 